Vol. No. 2, Issue No. 2, June, 2018,99-127

Copyright () IIUM Press

eISSN 2600-8432

\title{
A Prelimanary Survey of Issues of Shiism in Malaysia with Special Reference to the State of Malacca.
}

\author{
Hamzah Jantan* \\ W Mohd Azam bin Mohd Amin** \\ Amilah binti Awang Abd Rahman***
}

\begin{abstract}
This paper offers an introductory discussion of Shiism as one of the sect in Muslim schism. It includes the historical development of Shiism in Muslim traditions whose influence can be traced in Malaysia, specifically in Malacca. The author emphasises the clear distinction between the Shiite and the Ahl al-Bayt, and some issues of Shiism that drew the attention of religious authority in Malacca. A qualitative methodology that includes the textual analysis and interview method were employed to analyse textual materials related to Shiism. Findings shows that Malay Shiites group existed in Malacca as most of them were inspired by the Iranian revolution on 1979.
\end{abstract}

Keywords: Schism, Shiism, Sunnism, Malay, Melaka, Islamic History.

\footnotetext{
* Hamzah Jantan, a graduate student of the International Institute of Islamic Thought and Malay Civilization, International Islamic University, Malaysia, Kuala Lumpur. Email address: akhi.hamzah@email.com

** Dr. W Mohd Azam bin Mohd Amin, Associate Professor, Department of Usul al-din and Comparative Religion, Kulliyyah of Islamic Revealed Knowledge and Human Sciences, International Islamic University Malaysia, Kuala Lumpur. Email address: wmazam@iium.edu.my

*** Dr. Amilah binti Awang Abd Rahman Assistant Professor, Department of Usul aldin and Comparative Religion, Kulliyyah of Islamic Revealed Knowledge and Human Sciences, International Islamic University Malaysia, Kuala Lumpur. Email address: amilah@iium.edu.my
} 


\section{The Definition of $S h^{\top} \boldsymbol{A} h$}

The Arabic word of $S h \bar{\imath}$ 'ah renders multiple meanings. In $M u$ 'jam alMa 'āni al-Jamì', Shī'ah literally means al-firqah and al-jamā' ah which is a sect and a group. In al-Muqaddimah by Ibn Khaldūn (d.1406), Sh'̃ $a h$ means atbā'uh wa anșāruh which means supporters and assistances. ${ }^{1}$

Technically, $S h \bar{l}$ 'ah is a part of a group of Muslims who love 'Alī (d.661) and his family members. They believe that imamah or imamate or leadership must come from 'Alî's descendants. ${ }^{2}$ According to Shahrastānī (d.1153), Shī'ah refers to the followers of 'Alī and the imamate must remain with 'Alī's lineage. Basically, Shiism can be identified by the fundamental doctrines in their teachings. In spite of the issue of imamate which is the root of Shiism, other doctrines such as dissimulation (taqiyyah), temporary marriage (nikāh mut'ah) and infallibility of the House of the prophet ('ișmah Ahl al-Bayt) are the characteristic to recognize Shiism.

Furthermore, all Shiite sects hold that 'Alī $\mathrm{s}$ is the continuation of the legitimacy of the Prophet in which needs to be taken seriously. The issue of the imamate is not a civil matter which can be decided by people yet, it is a fundamental belief and a basic element of the religion. ${ }^{3}$ It is impossible for a messenger of God to neither ignore and disregard it, nor leave it to the choice of the ordinary people. However, each group had its own imām and disagreements among them about the rightful imām to be followed. In fact, the dispute regarding the rightful imām dragged them into sectarian conflict which resulted the groups such as Kaysāniyyah, Zaydiyyah, Imāmiyyah, Ghāliyyah and Ismā 'îliyyah. ${ }^{4}$

\footnotetext{
${ }^{1}$ Abū Zayd 'Abd al-Raḥmān ibn Muhammad ibn Khaldūn al-Ḥaḍramī, Al-Muqaddimah, tr. Franz Rosenthal, Muqaddimah, vol. 1, $2^{\text {nd }}$ edition, (New Jersey: Princeton University Press, 1967), 402, Muhammad b. 'Abd al-Karīm Shahrastān̄̄, Kitāb al-Milal wa al-Niḥal, tr. A.K. Kazi and J. G. Flynn, Muslim Sects and Division, (London, Kegan Paul International 1984), 125.

${ }^{2}$ Ibid.

3 Ibid; Al-Bir Nașr Nadīr, Madkhal ilā al-Firaq al-Islāmiyyah: Al-Siyāsah wa alKalāmiyyah, (Bayrut: Dar al-Mashriq, 1989), pp. 18-19, 'Alī 'Abd al-Fattāḥ alMaghrib̄i, Al-Firaq al-Kalāmiyyah al-Islāmiyyah: Madkhal wa Dirāsatuh, (AlQāhirah: Maktabah al-Wahbah, 1995), p. 146.

${ }^{4}$ Ibid.
} 
The word ' $S h \bar{l}$ ' $a h$ '5 is mentioned in the Qur'an four times ${ }^{6}$ which are in (Sürah al-Săffāt verse, 83), (Sürah Maryam verse, 69), and two times in (Sürah al-Qașaș verse, 15). Sayyīd Quṭb in his masterpiece Fī zilālal-Qur'àn explains the usage of the word Shī'ah. Firstly, (Sürah alSâffāt, verse, 83) refers to the Prophet Ibrahim P.B.U.H. himself where he was the successor of the Prophet Nūh P.B.U.H, bringing the message of tawhìd and fighting idol worshippers. Secondly, the (Sürah Maryam verse, 69) uses the word to refer to a group because this verse portrays the scenes in the hell where a group of people who go against Allah would be punished. Thirdly, the (Sürah al-Qașaș verse, 15) uses the word as a group, a clan or a tribe because the verse tells a story of the Prophet Mūsa P.B.U.H who defended one of his people in a fight. Therefore, these three meanings of the word $S h \bar{l}$ 'ah connote different interpretations based on its usage in specific words but the context verses remain the same.

In the nutshell, the word Shi' $a h$ has never been interpreted and understood as an exclusive term referring to the sect of $S h \bar{l}^{\prime} a h$ in the early age of Islam. It emerges later due to political development which contextualized its meaning. The usage of this word was modified. Its general meaning has changed to a specific connotation, which limits it usage to the understanding of Shiism. In general, there are two versions of how Shiism originated. Firstly, it is originated from the religious doctrine and secondly, it began with the political thought.

As far as Shiism is concerned, some scholars argue that Shiism emerged from religious doctrine. ${ }^{7}$ This opinion can be divided into three categories. Firstly, some say that Shiism is originally created by Persian converts. ${ }^{8}$ They argue that Persia had applied hereditary monarchy before the coming of Islam. Hence, these converts brought their previous belief system and thought that 'Ali and his descendants are the true legacy of the prophets. ${ }^{9}$ Moreover, the nature of the tribal system in the

\footnotetext{
${ }^{5}$ The word $S h \bar{\imath}$ ' $a h$ in this study will be utilized as Shiite or Shiism afterwards due to universal usage in academic writing.

6 Maḥmūd Muhammad Mazrū'ah, Al-Firaq al-Islāmiyyah, (Madīnah: Dār al-Riḍā, 2008), 188-191; al-Islāmiyyah: Madkhal wa Dirāsatuh, (Al-Qāāirah: Maktab alWahbah, 1995), 137.

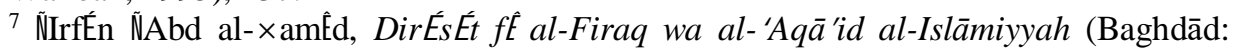
Mal̈ba'ah al-Irshād, 1967), 22

${ }^{8}$ Ibid.

${ }^{9}$ Ibid.
} 
Arab peninsular itself is rough, rebellious and antagonistic, and contradict with the hereditary monarchy principle which demand a slave like obedience and loyalty. ${ }^{10}$ Thus, the doctrine of inheritance of monarchy in Persian culture had been exported to Islam, resulting in the theological framework of Shiism.

Secondly, the formation of Shiism is based on the plans of the Jewish convert, 'Abd Allāh bin Sabā'. ${ }^{11}$ According to this theory, he converted to Islam in Yemen during the reign of Caliph 'Uthmān (d.656), went to different parts of the Muslim territory of the time, especially Damascus, Kūfah, Bașrah and Egypt. He proclaimed that the Prophet MuÍammad would return to this world and 'Alī was the Prophet's successor since every prophet has a successor. ${ }^{12}$ Besides, he was alleged the one who proposed the idea that 'Uthmān hijacked 'Alî̀'s position of leadership and therefore people need to fight against 'Uthmān to ensure justice would be upheld. ${ }^{13}$ 'Abd Allāh bin Sabā' succeeded to form a group of people who sympathised with 'Alī and his descendants whose rights, they believe were denied. Therefore, the role of 'Abd Allāh bin Sabā' to impose his beliefs and doctrine had shaken the unity between Muslim ummah which later led to a split into many sects including Shiism. However, there was disagreement among scholars on 'Abd Allāh bin Sabā's personality.

Thirdly, some scholars suggest that Shiism was originated by some South Arabian tribes. ${ }^{14}$ The communities in the Southern Arab have a systematical way of life, socio-political and socio-religious institutions. Moreover, they believe that kings are demi-gods. ${ }^{15}$ For instance, a South Arabian prince, in his votive inscriptions, thanked the gods who made him victorious over his enemies and warriors erected memorials to their divine helper for any success they achieved. In fact, the South Arabian tribes believed this, embraced Islam eventually. ${ }^{16}$ As a matter of fact, they were still influenced with the ideas of the divinity or the possession of supreme power of kings and leaders from their previous religions. Hence, Southern Arabs tend to perceive that the Household of the

\footnotetext{
10 Ibid.

${ }^{11}$ Ibid., p. 27.

12 Ibid., p. 51.

${ }^{13}$ Ibid.

${ }^{14}$ Ibid., p. 31.

${ }^{15}$ Ibid.

${ }^{16}$ Ibid.
} 
Prophet as the legitimate heir for the position of the imām or leader in which the presence of Shiism is detected.

In terms of political thought, there are several opinions about it among classical and modern scholars. ${ }^{17}$ Firstly, Abū Zahrah (d.1974) states that Shiism began after the death of 'Uthmān and developed in the period of 'Alī's caliphate. ${ }^{18}$ Secondly, Watt explains that the emergence of Shiism happened during the Șiffin war between the supporter of 'Alī and $\mathrm{Mu}$ 'āwiyah (d. 680). ${ }^{19}$ As the result of accepting reconciliation from $\mathrm{Mu}$ 'āwiyah's group, 'Alī's supporters were divided into two groups who are pro-'Alī (Shī'ah) and anti-'Alī (Khawārij). Thirdly, Ibn Nadīm (d.990) believes that Shiism started after the war of Jamāl, when 'Alī went to fight Țalhah (d. 656), Zubayr (d. 656) and ' $\bar{A}$ 'ishah (d. 678). ${ }^{20}$ Fourthly, the killing of 'Alī is the main key that led to the existence of Shiism, which is mentioned by the historian Țāha Husayn (d.1973). ${ }^{21}$ Fifthly, Ahmad Amīn (d.1954) views that Shiism begin after the death of the Prophet simultaneously, where the issue of imamate and caliphate have been debated among the Companions in Thaqîfah bani $\mathrm{Sa}$ 'ìdah. ${ }^{22}$ Sixthly, Shiite scholars such as al-Nawbakhtī (d.938) and al-'Āmilī (d.1621) explain that Shiism has existed since the time of the Prophet where the Prophet himself appointed 'Alī as his successor (walī) in the event of Ghadir Khum. ${ }^{23}$ From these opinions, it is clears that the emergence of Shiism undeniable even though the scholars have different theories. Hence, all opinions seem to have logical and rational evidence which need to be evaluated precisely.

After analysing on this matter, it can be concluded that the emergence of Shiism originated from the political thought framework. The basic element which becomes a controversial argument and dispute throughout history is the issue of imamate or leadership. It could simply be viewed from the opinions of scholars who mainly stressed on the possession of power. From this point, the political thought has slowly

17 Duncan B. Macdonald, Development of Muslim Theology, Jurisprudence and Constitutional Theory, (New York: Charles Scribner's Sons, 1903).

${ }^{18}$ Muḥammad Abū Zahrah, Tārīkh al-Madhāhib al-Islāmiyyah, vol. 1 (Cairo: Dār alFikr al-'Arabī, 1960), 13.

19 W. Montgomery Watt, The Formative Period of Islamic Thought, (Edinburgh: Edinburgh University Press, 1973), 107.

${ }^{20}$ Abū Zahrah, Tārīkh al-Madhāhib al-Islāmiyyah, 13.

${ }^{21}$ Ibid., 14.

${ }^{22}$ Ibid.

${ }^{23}$ Ibid. 
evolved to a new phase in which religious doctrine has been presented fanatic and extreme followers. In other words, Shiism originated from the issue of leadership that definitely related to political thought and the religious doctrines which existed due to the influence of fanaticism and extremism. Furthermore, the opinion that stated Shiism has started after the death of 'Uthmān and developed in the time of 'Alī is the most logical and reliable theory about the existence of Shiism. The reason to support this theory is because in the time of the Caliphs Abu Bakar (d. 634) and 'Umar (d. 644), the unity and bond among the Muslims were solid and unshakeable. There was no sect within the Muslim community as every Muslim united as one ummah. Only after the death of 'Uthmān, that the element of Shiism was manifested publicly, resulting in the existence of groups such as the Kharijite and the Shiite. Besides that, there is a hadith of the Prophet about the great upheaval (al-fitnah al$k u b r \bar{a}$ ) which would befall into 'Uthmān. It was narrated by Abū Mūsā Al-'Ash'arī (d. 662) in an occasion where he guarded the gate of the garden when the prophet was inside. After that, Abū Bakar came first and asked for permission to enter the garden, followed by 'Umar. Both of them were given the permission to enter the garden to meet the Prophet and had been informed with the news that they would enter the Paradise. When 'Uthmān came, the prophet said;

"Admit him and give him the glad tidings of entering Paradise with a calamity which will befall him." When he entered, he could not find any place to sit with them so he went to the other edge of the well opposite them and uncovered his legs and hung them in the well. I wished that a brother of mine would come, so I invoked Allah for his coming. (ibn al-Musayyib said, "I interpreted that (narration) as indicating their graves. The first three are together and the grave of 'Uthmān is separate from theirs." $)^{24}$

From the hadìth above, it seems that the Prophet hinted what would wait 'Uthmān in the future by reminding him that he would face catastrophe. A few years later, he was killed at the hands of the fellow Muslims. From this incident, the Muslim ummah separated into many sects that resulted in the emergence of Shiism in Islamic history. Thus,

\footnotetext{
${ }^{24}$ Muhammad bin Ismā‘īl al-Bukhārī, al- Jāmi ‘ al-Sahāhh al-Bukhārī (Al-Qāhirah: alMaktabah al-Salafiyah, 1980), 7186.
} 
the opinions regarding the exact period when Shiism emerged differ. But, no one can deny that the influence of Shiism in the Muslim world is significant especially in the present time.

\section{The Origin of Shiism}

In general, there are two versions of how Shiism originated. Firstly, it is originated from the religious doctrine and secondly, it began with the political thought.

As far as Shiism is concerned, some scholars argue that Shiism emerged from religious doctrine. ${ }^{25}$ This opinion can be divided into three categories. Firstly, some say that Shiism is originally created by Persian converts. ${ }^{26}$ They argue that Persia had applied hereditary monarchy before the coming of Islam. Hence, these converts brought their previous belief system and thought that 'Ali and his descendants are the true legacy of the prophets. ${ }^{27}$ Moreover, the nature of the tribal system in the Arab peninsular itself is rough, rebellious and antagonistic, and contradict with the hereditary monarchy principle which demand a slave like obedience and loyalty. ${ }^{28}$ Thus, the doctrine of inheritance of monarchy in Persian culture had been exported to Islam, resulting in the theological framework of Shiism.

Secondly, the formation of Shiism is based on the plans of the Jewish convert, 'Abd Allāh bin Sabā', ${ }^{29}$ According to this theory, he converted to Islam in Yemen during the reign of Caliph 'Uthmān (d.656), went to different parts of the Muslim territory of the time, especially Damascus, Kūfah, Bașrah and Egypt. He proclaimed that the Prophet MuÍammad would return to this world and 'Alī was the Prophet's successor since every prophet has a successor. ${ }^{30}$ Besides, he was alleged the one who proposed the idea that 'Uthmān hijacked 'Alī's position of leadership and therefore people need to fight against 'Uthmān to ensure justice would be upheld. ${ }^{31}$ 'Abd Allāh bin Sabā' succeeded to form a group of people who sympathised with 'Alī and his

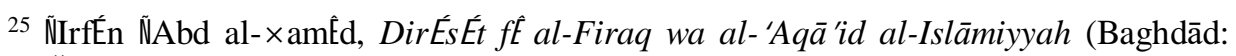
Mä̈ba'ah al-Irshād, 1967), p. 22.

${ }^{26}$ Ibid.

${ }^{27}$ Ibid.

28 Ibid.

${ }^{29}$ Ibid., p. 27.

${ }^{30}$ Ibid., p. 51.

${ }^{31}$ Ibid. 
descendants whose rights, they believe were denied. Therefore, the role of 'Abd Allāh bin Sabā' to impose his beliefs and doctrine had shaken the unity between Muslim ummah which later led to a split into many sects including Shiism. However, there was disagreement among scholars on 'Abd Allāh bin Sabā's personality.

Thirdly, some scholars suggest that Shiism was originated by some South Arabian tribes. ${ }^{32}$ The communities in the Southern Arab have a systematical way of life, socio-political and socio-religious institutions. Moreover, they believe that kings are demi-gods. ${ }^{33}$ For instance, a South Arabian prince, in his votive inscriptions, thanked the gods who made him victorious over his enemies and warriors erected memorials to their divine helper for any success they achieved. In fact, the South Arabian tribes believed this, embraced Islam eventually. ${ }^{34}$ As a matter of fact, they were still influenced with the ideas of the divinity or the possession of supreme power of kings and leaders from their previous religions. Hence, Southern Arabs tend to perceive that the Household of the Prophet as the legitimate heir for the position of the imām or leader in which the presence of Shiism is detected.

In terms of political thought, there are several opinions about it among classical and modern scholars. ${ }^{35}$ Firstly, Abū Zahrah (d.1974) states that Shiism began after the death of 'Uthmān and developed in the period of 'Alī's caliphate. ${ }^{36}$ Secondly, Watt explains that the emergence of Shiism happened during the Șiffīn war between the supporter of 'Alī and $\mathrm{Mu}$ 'āwiyah (d. 680). ${ }^{37}$ As the result of accepting reconciliation from $\mathrm{Mu}$ 'āwiyah's group, 'Alī's supporters were divided into two groups who are pro-'Alī (Shī'ah) and anti-'Alī (Khawārij). Thirdly, Ibn Nadīm (d.990) believes that Shiism started after the war of Jamāl, when 'Alī went to fight Țalhah (d. 656), Zubayr (d. 656) and ' $\bar{A}$ 'ishah (d. 678). ${ }^{38}$ Fourthly, the killing of 'Alī is the main key that led to the existence of

\footnotetext{
32 Ibid., 31.

${ }^{33}$ Ibid.

${ }^{34}$ Ibid.

35 Duncan B. Macdonald, Development of Muslim Theology, Jurisprudence and Constitutional Theory, (New York: Charles Scribner's Sons, 1903).

${ }^{36}$ Muhammad Abū Zahrah, Tārīkh al-Madhāhib al-Islāmiyyah, vol. 1 (Cairo: Dār alFikr al-'Arabī, 1960), p. 13.

37 W. Montgomery Watt, The Formative Period of Islamic Thought, (Edinburgh: Edinburgh University Press, 1973), p. 107.

${ }^{38}$ Abū Zahrah, Tārīkh al-Madhāhib al-Islāmiyyah, p. 13.
} 
Shiism, which is mentioned by the historian Țāha Husayn (d.1973). ${ }^{39}$ Fifthly, Ahmad Amīn (d.1954) views that Shiism begin after the death of the Prophet simultaneously, where the issue of imamate and caliphate have been debated among the Companions in Thaqîfah banī $S a{ }^{\prime} \bar{\imath} d a h{ }^{40}$ Sixthly, Shiite scholars such as al-Nawbakhtī (d.938) and al- 'Āmilī (d.1621) explain that Shiism has existed since the time of the Prophet where the Prophet himself appointed 'Alī as his successor (walī) in the event of Ghadir Khum. ${ }^{41}$ From these opinions, it is clears that the emergence of Shiism undeniable even though the scholars have different theories. Hence, all opinions seem to have logical and rational evidence which need to be evaluated precisely.

After analysing on this matter, it can be concluded that the emergence of Shiism originated from the political thought framework. The basic element which becomes a controversial argument and dispute throughout history is the issue of imamate or leadership. It could simply be viewed from the opinions of scholars who mainly stressed on the possession of power. From this point, the political thought has slowly evolved to a new phase in which religious doctrine has been presented fanatic and extreme followers. In other words, Shiism originated from the issue of leadership that definitely related to political thought and the religious doctrines which existed due to the influence of fanaticism and extremism. Furthermore, the opinion that stated Shiism has started after the death of 'Uthmān and developed in the time of 'Alī is the most logical and reliable theory about the existence of Shiism. The reason to support this theory is because in the time of the Caliphs Abu Bakar (d. 634) and 'Umar (d. 644), the unity and bond among the Muslims were solid and unshakeable. There was no sect within the Muslim community as every Muslim united as one ummah. Only after the death of 'Uthmān, that the element of Shiism was manifested publicly, resulting in the existence of groups such as the Kharijite and the Shiite. Besides that, there is a hadith of the Prophet about the great upheaval (al-fitnah al$k u b r a \overline{)}$ ) which would befall into 'Uthmān. It was narrated by Abū Mūsā Al-'Ash'arī (d. 662) in an occasion where he guarded the gate of the garden when the prophet was inside. After that, Abū Bakar came first and asked for permission to enter the garden, followed by 'Umar. Both of them were given the permission to enter the garden to meet the

\footnotetext{
${ }^{39}$ Ibid., p. 14.

${ }^{40}$ Ibid.

${ }^{41}$ Ibid.
} 
Prophet and had been informed with the news that they would enter the Paradise. When 'Uthmān came, the prophet said;

"Admit him and give him the glad tidings of entering Paradise with a calamity which will befall him." When he entered, he could not find any place to sit with them so he went to the other edge of the well opposite them and uncovered his legs and hung them in the well. I wished that a brother of mine would come, so I invoked Allah for his coming. (ibn al-Musayyib said, "I interpreted that (narration) as indicating their graves. The first three are together and the grave of 'Uthmān is separate from theirs." $)^{42}$

From the hadith above, it seems that the Prophet hinted what would wait 'Uthmān in the future by reminding him that he would face catastrophe. A few years later, he was killed at the hands of the fellow Muslims. From this incident, the Muslim ummah separated into many sects that resulted in the emergence of Shiism in Islamic history. Thus, the opinions regarding the exact period when Shiism emerged differ. But, no one can deny that the influence of Shiism in the Muslim world is significant especially in the present time.

\section{Ahl Al-Bayt and Shiism}

Literally, the term ahl signifies the members of a household of a man, including his fellow tribesmen, kin, relatives, wife (or wives), children and those who share a common family background, religion, house, city, and country with him. ${ }^{43}$ In fact, "ahl" and " $\bar{l} l$ " both share the same term except that "âl" is exclusively used for human beings and should come before the family name. But such a condition does not exist in the case of " $a h l$ ". ${ }^{44}$ Meanwhile, bayt refers to habitation and dwelling, including tents and buildings. ${ }^{45}$ Thus, the Ahl al-Bayt of any person refers to his family members and those who live in his house. ${ }^{46}$ Besides, the word $A h l$

\footnotetext{
${ }^{42}$ Muḥammad bin Ismā'īl al-Bukhārī, al- Jāmi ‘ al-Ṣahīh al-Bukhārī (Al-Qāhirah: alMaktabah al-Salafiyah, 1980), p. 7186.

${ }^{43}$ Muhammad bin Mukram ibn Manẓūr, Lisān al- 'Arab, (Bayrūt: Dār al-Fikr, 1970), 11, p. 28.

${ }^{44}$ Ibid., p. 29.

45 Abū al-Qāsim al-Ḥusayn ibn Muḥammad Rāghib al-Aṣfahān̄̄, Mufradāt Alfāz alQur'ān (Dimashq: Dar al-Qalam, 2002), p. 235.

${ }^{46}$ Ibid.
} 
al-Bayt has been stated explicitly in the (Sürah al-Ah̆zāb verse, 33);

"And abide in your houses and do not display yourselves as (was) the display of the former times of ignorance. And establish prayer and give zakāh and obey Allah and His Messenger. Verily Allah intends only to remove from you the impurity [of sin], O people of the (Prophet's) household, and to purify you with (extensive) purification."

From the verse above, it can be understood that the Ahl al-Bayt means the prophet's household. Nevertheless, the discussion on who is Ahl al-Bayt has invited multiple opinions among the Muslim sects in which can be analysed from Sunnite and Shiite perspectives.

The Shiite group has a different understanding and perspective with regard to the concept of Ahl al-Bayt. According to the Shiites, Ahl alBayt has been stated in the Qur'an (Sürah al-Ahzzāb verse, 33), "...Verily Allah intends to keep off from you every kind of uncleanness O' People of the House (Ahl al-Bayt), and purify you with a perfect purification." 47 From this verse, Ahl al-Bayt has been purified by Allah from sin, mistake, and forgetfulness since the verse specifically refers to them ${ }^{48}$. Moreover, the word al-Rijs in that verse has the article "al" at its beginning which makes the word universal. Thus al-Rijs means every kind of impurity. ${ }^{49}$ Moreover, at the end of the verse, Allah states; "and purify you a perfect purification." 50 The word "perfect" comes from the emphasis of "tathiran". ${ }^{51}$ This is the only place in the Qur'an that Allah uses the emphasis of perfect purification.

Furthermore, Shiite groups believe that Ahl al-Bayt consists of Prophet's daughter Fāțimah, his son in-law and cousin 'Alī, and his two grandchildren al-Hassan (d.670) and al-Husayn (d.680). ${ }^{52}$ Through the progeny of al-Husayn, there are nine designated imāms. ${ }^{53}$ 'Alī Zayn al-

\footnotetext{
${ }^{47}$ Muassasah al-Balagh, Ahl al-Bayt: Maqāmuhum Manhajuhum Masāruhum (Iran: AlBalagh Foundation, 1977), 5-6.

${ }^{48}$ Ibid., p. 8.

${ }^{49}$ Ibid., p. 13.

${ }^{50}$ Ibid., p. 14.

${ }^{51}$ Ibid.

52 Ibid., p. 12.

53 The designated imām mentioned above referring to Ithnā 'Ashariyyah or Twelver. The Twelver is an influential and powerful Shiite sect nowadays as they represented Shiism as a whole.
} 
'Ābidīn (d.713), Al-Bāqir (d.743), Al-Ṣādiq (d.765), Al-Kāzim (d.799), Al-Riḍā (d.819), Al-Taqī (d.835), Al-Hādī (d.868), Al-‘Askarī (d.874) and Al-Mahdī (hidden in Samarrā') ${ }^{54}$ In fact, this is a group which consistently associate themselves with Ahl al-Bayt, the true supporters and followers of them.

To be more certain, the Shiites utilise a hadìth from Sahịh Muslim in which there is a chapter named Chapter of Virtues of the Companions. Inside this chapter, there is a section called Section of the Virtues of the Ahl al-Bayt of the Prophet. ${ }^{55}$ This section includes a hadith of Cloak or Mantle (hadith al-kis $\bar{a}^{\prime}$ ) and it has no reference to the wives of the Prophet. ${ }^{56}$ Narrated 'A''ishah;

One day the Prophet P.B.U.H came out afternoon wearing a black cloak (upper garment or gown or long coat), then al-Hassan b. 'Ali came and the Prophet accommodated him under the cloak, then al-Husayn came and entered the cloak, then Fătimah came and the Prophet entered her under the cloak, then 'Ali came and the Prophet entered him to the cloak as well. Then the Prophet recited: "Verily Allah intends to keep off from you every kind of uncleanness O' People of the House (Ahl al-Bayt), and purify you a perfect purification (the last sentence of Sūrah al-Ahzzāb 33)." 57

So, these are some of the arguments utilised by the Shiites to support the claim that Ahl al-Bayt exclusively consists of 'Alī, Fāțimah, al-Hassan, al-Husayn and the chosen descendants of al-Husayn. They excluded the wives of the prophet from Ahl al-Bayt because the wives of the prophet did not belong to aṣhāb al-kisā' (people who are under a garment). ${ }^{58}$

On the other hand, the Sunnites or Ahl Sunnah wa al-Jama' 'ah is a sect who loves and respects Ahl al-Bayt. No one has denied the special element and position of Ahl al-Bayt that has been guaranteed in Islam as all of them belong to the family of the Prophet. Furthermore, there are

\footnotetext{
${ }^{54}$ Iḥsān Ilāhī Ẓāhir, Al-Shī'ah wa Ahl al-Bayt (Al-Qāhirah: Dār al-I'tișām, 1986), 22.

55 Sạn̄ị Muslim Book 31, hadīth 5920.

${ }^{56}$ Ihsān Ilāhī Zāhir, Al-Shī'ah wa Ahl al-Bayt, p. 56.

57 Sahīh Muslim, Chapter of virtues of companions, section of the virtues of the Ahl alBayt of the Prophet, vol.4, p. 1883, hadith 61.

${ }^{58}$ Muassasah al-Balagh, p. 12-13.
} 
many opinions among Sunnite scholars regarding this issue because in the Sunnite sect there is a different orientation and understanding of the members of Ahl al-Bayt. However, this is just a matter of variety in opinion since all of them have never rejected the concept of Ahl al-Bayt. Hence, the main opinion on who are the members of Ahl al-Bayt can be categorised into four opinions ${ }^{59}$ from the Sunnite perspective.

Firstly, Ahl al-Bayt (The People of the House of the Prophet) is the family members of the prophet who are unlawful to receive zakatt as the Prophet ordered all Muslims to respect, honour, and follow. ${ }^{60}$ Indeed, Ahl al-Bayt includes three groups of people, the first group is 'Alī , Fățimah, al-Hassan and al-Husayn, the second group is the wives of the Prophet and the last group is the family of 'Aqīl (d.682), the family of Ja'far (d.629) and the family of 'Abbās (d.653). This opinion is held by most of the prominent Muslim scholars like al-Shāfi'í (d.820), Abū Hanīfah (d.767) and some of the scholars of Mālikite school ${ }^{61}$. The reason of this opinion is related to a hadith from Muslim (Sahīh Muslim no. 2408);

"He exhorted (us) (to hold fast) to the Book of Allah and then said: The second are the members of my household I remind you (of your duties) to the members of my family. He (al-Husayn) said to Zayd: Who are the members of his household? Aren't his wives the members of his family? Thereupon he said: His wives are the members of his family (but here) the members of his family are those for whom acceptance of zakat is forbidden. And he said: Who are they? Thereupon he said: "Alī and the offspring of 'Alī, 'Aqīl and the offspring of 'Aqīl and the offspring of Ja'far and the offspring of 'Abbās. Al-Husayn said: These are those for whom the acceptance of zakat is forbidden. Zayd said: Yes."62

Secondly, Ahl al-Bayt refers only to the wives and children of the Prophet Muhammad. ${ }^{63}$ A hadīth of al-Bukhārī ${ }^{64}$ can be seen as evidence

\footnotetext{
${ }^{59}$ Sulaymān ibn Rajā' al-Samhīi, Al- 'Aqīdah Ahl al-Bayt bayna al-Ifrāt wa al-Tafrīt, vol.1 (Riyāḍ: Dar Aḍ̂ā’ al-Salaf, 2004), p. 55.

${ }^{60}$ Ibid.

61 Ibid.

${ }^{62}$ Ibid., p. 58.

${ }^{63}$ Ibid., p. 61.
} 
to support this claim;

Abū Ḥumayd Al-Sa'dī said:

The people asked, "O Allah's Messenger! How shall we (ask Allah to) send blessings on you?" Allah's Apostle replied, "Say: O Allah! Send Your Mercy on Muhammad and on his wives and on his offspring, as You sent Your Mercy on Abraham's family; and send Your Blessings on Muhammad and on his offspring, as You sent Your Blessings on Abraham's family, for You are the Most Praiseworthy, the Most Glorious."

This opinion has been supported by few Sunnite scholars like Aḥmad bin Hanbal (d.855), ibn 'Abd al-Barr (d.1071), ibn al-'Arabī alAndalūsī (d.1240), and ibn Taymiyyah (d.1328). Thus, this opinion limits the members of Ahl al-Bayt to only for the wives and the children of the Prophet alone.

Thirdly, Ahl al-Bayt is meant for all followers of the prophet Muhammad $^{65}$ till the Day of Judgment, as they argue using a hadith from Ahmad; ${ }^{66}$

Wāthilah bin al-Asqā ${ }^{67}$ narrated that the Prophet PBUH called for al-Hassan and al-Husayn and he made each one sit on a side of his lap and he came closer to Fātima and her husband while I stood alone. Then he surrounded them with a cloak and said: "God wants to remove all kinds of uncleanliness from you Ahl al-Bayt and to purify you thoroughly." O Allah they are my $a h l$ and my $a h l$ are more deserving. I said: O prophet of Allah! Am I not from your $a h l$ ? He said: And you are from my ahl."

It is understood from the hadith above which stated that a pious Muslim is also considered as Ahl al-Bayt since the Prophet told Wāthilah bin al-Asqā' that he belongs to the Prophet's family. Several scholars like al-Azharī (d.980), al-Safārīn̄i (d.1703) from the Shāfiñite School

\footnotetext{
${ }^{64}$ Sahịh al-Bukhārī, hadīth no. 3369.

65 Sulaymān bin Rajā', 65.

${ }^{66}$ Ahmad, Musnad, 4: no. 107

${ }^{67}$ Wāthilah bin al-Asqa' comes from the tribe of Layth bin Bakar bin 'Abd Munāh and he is one of the prophet's followers.
} 
and al-Mardāwī (d.1552) from the Hanbalite School are among the scholars who hold this view. Therefore, the hadith above has given clarification of this opinion.

Lastly, there is a group who believe that Ahl al-Bayt comes from the pious ummah of the Prophet based of a hadīth from al-Ṭabarānī (d.918);

From a narration of Nūḥ bin Abī Maryam from Yahyā bin Sa'īd al-Anșārī from Anas bin Mālik said: A prophet had been asked, who is the family of prophet? Prophet said every Pious (Muslim) and he recited a verse of Qur'an (alAnfāl: 34) ((No men can be its guardians except the righteous) $).{ }^{68}$

The hadith above has been used by some Sunnite scholars to support their claim that Ahl al-Bayt has a broader meaning that encompasses all Muslims who are pious and righteous. In other words, Ahl al-Bayt can be anyone who is a Muslim and it is not limited to linage. There are some scholars who support this opinion like Qāḍi Husayn al-Marwāzī (d.873) from the Shāfi'ìte school and one group from Hanbalite school.

From these four opinions among Sunnite scholars, each of them has provided evidence to support the statement. Yet, after analysing each opinion proposed by Sunnite scholars, the opinion which stated that $A h l$ al-Bayt consists of 'Alī , Fạțimah, al-Ḥassan, al-Husayn, the wives of the prophet, the family of 'Aqīl, Ja'far and 'Abbās is the best opinion because the Prophet himself mentioned them specifically by name in the Sahịh Muslim ${ }^{69}$ with an authentic chain of narrators. Even though the second opinion comes with valid evidence which minimises the members of Ahl al-Bayt only to the wives and children of the Prophet, the majority of Muslim scholars tend to support the first opinion. Nevertheless, this is only the matter of ijtiha $\bar{a}$ which does not affect a Muslim's conviction. Thus, the truth is Ahl al-Bayt is a Household of the Prophet who has to be respected and loved and this is what Sunnite Muslims have been taught and believed.

To see a relation between Shiism and Ahl al-Bayt is incorrect since there are numbers of narrations from the Ahl al-Bayt themselves who strongly reject the doctrines of the Shiism. They disassociate themselves

${ }^{68}$ A status of hadīth is da î̉ according to Yahyā bin Ma'īn (d. 847)

${ }^{69}$ Muslim, hadīth no. 2408 
from becoming involved with the extreme group of people which was al-Räfị (Shiism). One of the members of Ahl al-Bayt, 'Alī ibn alHusayn Zayn al-'Ābidīn (d.713) commented when he was linked with the Shiites;

"Some of the followers will love us (Ahl al-Bayt) till what the Jews had told 'Uzayr, the Christians had told the Prophet Isa P.B.U.H, they were not from us and we were not from them."70

Ja'far al-Șādiq (d.765) said to one of his followers,

"O Jabir, news has come to me that there are sum of people who claimed that they loved me in Iraq have insulted Abū Bakar and 'Umar, they said that I ordered them. Tell them that I for God's name I purified myself from them. For God's name, if I have power, surely I will come closure to God with their blood."71

'Alī said;

Perish for those who love me exaggeratedly, he glorified me with nothing that I able to, for those who hated me, till hate driving to accused me with things that I not able to."

Al-Dāruqutn̄̄ (d.995) narrated from 'Alī from Prophet Muhammad;

There is a time where raise a group entitled Räfidah. Ali said; O prophet what is a sign? They praise you with what is in you and accuse the Salaf. ${ }^{73}$

From the statements made by the members of Ahl al-Bayt, it implies that Shiism have nothing to do with Ahl al-Bayt since the members of Ahl al-Bayt themselves condemned for their beliefs of apostasy of the Companions of the Prophet. Ahl al-Bayt praises the companions as much as they adore the companions by following the advice and guidance

\footnotetext{
${ }^{70}$ Abū Zahrah, p. 38.

${ }^{71}$ Ibid., p. 42.

${ }^{72}$ Ibid., p. 46.

${ }^{73}$ Ibid., p. 37.
} 
taught by them. Therefore, Ahl al-Bayt is a part of Ahl al-Sunnah wa al$J a m \bar{a}$ 'ah which is the majority of the Muslim population.

Despite that, the concept of Ahl al-Bayt in Shiism is very influential that it has formed many doctrines in Shiite teaching. For example, the place of the rightful imām and religious leadership in Shiism must come from the descendants of the Prophet which is Ahl al-Bayt. This is the official belief of the Shiite sects except the Zaydite and a few other groups. Unlike the Sunnites who do not subscribe to the thought and understanding of religious leadership, the role of Ahl al-Bayt never came to this point. In fact, the concept of imämah in Shiism has developed from the issue of determining of the Ahl al-Bayt. Hence, the concept of Ahl al-Bayt plays an important part of Shiism.

To sum up, although the hadīth kisā' $\bar{\imath}$ is not the asbāb al-nuzūl of Sürah al-Ahzāb verse 33, it has been interpreted and understood as only five persons who are the Ahl al-Bayt; the Prophet, 'Alī, Fāṭimah, alHassan and al-Husayn by the Shiites. In other words, Shiism has minimised the members of Ahl al-Bayt to certain persons which signifies the exclusivity of this group. The concept of imamate which must be led by Ahl al-Bayt alone is the basis of their beliefs. So, it makes a clear distinction from the belief of the majority of Muslims.

\section{Shiite Groups}

In general, according to Shahrastānī (d.1328), the Shiites community can be classified into five groups the Kaysāniyah, the Zaydiyyah, the Imāmiyyah, the Ghulāt (the Extremist) and the Ismā'iliyyah. ${ }^{74}$ Within these groups, some of them are not considered as Muslims due to deviant beliefs and doctrines. ${ }^{75}$

\section{The Kaysāniyyah}

This sect originally comes from the followers of Kaysān who was a mawlā (servant) of 'Alī bin Abū Țālib. It has been said that he was a student of Muhammad al-Hanafiyyah (d.700). This sect believes in Kaysān who inherited the knowledge of all sciences and all secrets from his two masters ('Alī and Muḥammad al-Hanafiyyah). Furthermore, he possessed the power of allegorical interpretation insights into esoteric

\footnotetext{
${ }^{74}$ Shahrastān̄ī, al-Milal, p. 125.

${ }^{75}$ Ibid., p. 126.
} 
and it was said that he had knowledge of the heavens and the souls of men. This sect can be divided into another four sub-groups which are the Mukhtäriyyah, the Hāshimiyyah, the Bayāniyyah and the Rizämiyyah. Basically, all of these groups believe that after Prophet Muhammad died, the imamate is passed to Muhammad 'Alī al-Hanafiyyah. Then, it was inherited by the leaders from the four groups. ${ }^{76}$

\section{The Zaydīyyah}

This group of people belongs to the followers of Zayd (d.740) b. 'Alī b. al-Husayn b. 'Alī b. Abū Țâlib which held the belief that the imamate is legitimately passed down to the offspring of Fātimah; Any Fātimah descendents either from the House of al-Hassan or the House of alHusayn can be the imām if he is pious, learned, brave, generous and declares his imamate. Moreover, they support the possibility of having two imāms in different regions, where each has the right to allegiance. In theology, Zayd was influenced by the ideas of Mu'tazilism as he was a student of Wāṣil bin 'Ațā' (d. 748), a chief of the Mu'tazilites. Since Wāșil was his teacher, a few groups from Zaydite such as the Jārüdiyyah, the Sulaymāniyyah and the Batriyyah had opposed the controversial opinion of Wāșil that 'Alī b. Abū Țālib was not necessarily right to battle with the People of the Camel. Another point which brought them to disagreement was the legitimacy of the caliphate after the death of the Prophet. In this issue, Zayd proposed the view of almaf̣̂ul (a man of lesser excellence to be imām) even though al-af̣al (a man of greater excellence) exists. Zayd's example was in that time of the caliphate, Abū Bakar, 'Umar and 'Uthmān led the ummah even though 'Alī was there. Thus, these two ideas brought discrepancy among the Zaydites themselves, which led to the formation of three groups, the Jārüdiyyah, the Sulaymāniyyah and the Batriyyah. ${ }^{77}$

\section{The Imāmiyah (Ithnā 'Ashriyyah)}

This sect holds the view that the imamate rightfully belongs to "Alī with firm statements and clear appointment from the Prophet. In other words, the Prophet himself elected 'Alī as his successor to lead the ummah. The ummah needs an imām to continue the legacy of the Prophet and to

\footnotetext{
${ }^{76}$ Ibid., Abū Manșūr 'Abd al-Qāhir ibn Țāhir al-Baghdādī, Al-Farq Bayna al-Firaq, tr. Kate Chambers Seelye, (New Delhi: Cosmo Publications, 2011), pp. 47-49.

${ }^{77}$ Shahrastān̄̄, al-Milal, 132, Al-Baghdādī, al-Farq bayna al-firaq, pp. 43-49.
} 
guide them, so it is crucial in Islam. There is nothing more important than the appointment of an imām in the first place. They believe that an imām is selected by the indication of the Prophet himself, supported by the Quran and Sunnah. ${ }^{78}$ As a result, neglecting the imamate of 'Ali as a successor of the Prophet is the 'aqidah issue, a central belief among the Imāmiyah. Furthermore, they reject most of the Companions of the Prophet to the extent of degrading and slandering them, calling them traitors and unbelievers due to the issue of the imamate of "Alī.

Moreover, this sect is divided into a few groups such as the Nāwușiyyah, the Aftāhiyyah, the Müsāwiyyah, the Wāqifah and the Ithnā 'Ashriyyah (Twelver) due to the distinction in determining the imām after Ja'far al-Șādiq because he had five sons, some say six. ${ }^{80}$ From these children, some of them died without offspring, others left descendants. Some of the Imämiyah believe the return of an imām while others believe the continual transmission from one imām to another. ${ }^{81}$ The disagreement upon deciding the legitimate imām brought to the disunity among the Imāmiyah which then split the sect into numerous groups up to seventy groups. ${ }^{82}$

\section{The Ghäliyah and The Ismā'ïliyyah}

The Ghāliyah refers to a group whose views of their imām are extreme. They believe that their imāms are not bound with limitation and weaknesses of humanity. These imāms possess the divine qualities. In other words, the divine qualities possess within themselves are up to demigods for example, or more. There are many extreme groups of Shiism. Some of them are the Sabä'iyyah, the Kämiliyyah, the Mughìriyyah and the Manșüriyyah. Each group comes up with alien doctrines which contradict with the root and the basic teaching of Islam. ${ }^{83}$

The Ismā'îliyyah is a group who believes in the imamate of Ismā' 1 l, the eldest son of Ja'far. Unlike the Imämiyah who firmly holds that

\footnotetext{
78 Abū Muhammad al-Ḥassan bin Mūsā al-Nawbakhtī, Firaq al-Shī'ah, (Istanbul: Matba'ah al-Dawlah, 1931), p. 3.

${ }^{79}$ Ibid., p. 4.

${ }^{80}$ Ibid.

${ }^{81}$ Ibid., pp. 5-7.

82 Shahrastān̄i, al-Milal,139,145-149; Yahyyā Hāshim Hasan Farghal, Al-Farq alIslāmiyyah fi al-Mīzān, (Al-Qāhirah: Dār al-Āfāq al-'Arabiyyah, 2007), pp. 80-90.

${ }^{83}$ Shahrastān̄̄, al-Milal, 149; Yaḥyā Hāshim, Al-Farq al-Islāmiyyah, pp. 116-119.
} 


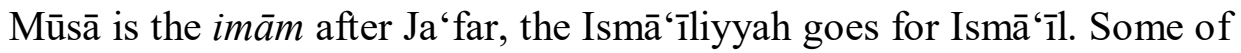
the Ismā'îliyyah believe Ismā'îl died during the lifetime of his father Ja'far and others believe that Ismā'ill died for the purpose of concealment, to hide from those who might seek to kill him. Furthermore, the Ismā' 'iliyyah is known as the Bătiniyyah. This is because of their belief that the meaning and understanding of 'exoteric' will always be followed by 'esoteric'. ${ }^{84}$ In other words, there are always multiple interpretations in the religious scripture. In fact, most of the doctrines and methods of this sect are inspired by the philosophical essence and framework, as they are closely related to Sufism.

\section{The Emergence and Development of Shiism in Malaysia}

Some scholars state that Shiism existed in $12^{\text {th }}$ century within the Muslim communities in Malay Archipelago. ${ }^{85}$ They suggest that the theory can be proven through manuscripts and literatures of like Bahr alLāhüt ${ }^{86}$ written by a certain Syeikh 'Abdullah 'Arif (d. c.1180). Although some of the Shiite ideas can be found in this book, in-depth analysis reveals that 'Abdullāh was a sufi who subscribe to the Qādiriyyah sufi order. ${ }^{87}$

The first trend of Shiism that came to the Malay world is the Bātiniyyah Shiite. ${ }^{88}$ The doctrines of Batinite such as Hulül wa Ittiḥād, Nür Muhammad and Rijäl al-Ghayb can be noticed from the group of mysticism who disseminated those doctrines in the Malay world. ${ }^{89}$ Several scholars like Sunan Kalijaga (d.1586), Syeikh Siti Jenar (d.1517), Hamzah Fansuri (d.1590) and Syamsuddin al-Sumaterani (d.1630) are among them who popularize the Batinite and wujüdiyyah

\footnotetext{
${ }^{84}$ Shahrastān̄̄, al-Milal, 163, 165-168; Muhammad Hamzah, Al-Ta'lluf bayna al-Firaq al-Islāmiyyah, (Damascus: Dār al-Qutaybah, 1985), p. 108-109.

85 Aizam Mas'ud, Soal Jawab Isu Syiah di Malaysia, (Putrajaya: Reka Cetak Sdn, Bhd., 2013), pp. 33-35.

${ }^{86}$ Bahr al-Lähüt is the earliest Taṣawwuf book in Malay world which contains the spiritual knowledge and discussion that are much influenced by the Qādiriyyah sufi order. Wan Mohd Saghir, "Syeikh Abdullah Penyebar Islam Pertama di Acheh", http://ww1.utusan.com.my/utusan/info.asp?y=2006\&dt=1113\&pubutusan_malaysia\& sec=BicaraAgama\&pg=ba_01.htm\&arc=hive, retrieved on 12-6-2018.

${ }^{87}$ Ibid.

88 Aizam Mas'ud, Soal Jawab Isu Syiah di Malaysia, (Putrajaya: Reka Cetak Sdn, Bhd., 2013), pp. 33-35.

${ }^{89}$ Ibid.
} 
(unity of being) doctrines. ${ }^{90}$ Thus, the influence of Batinite group over mysticism is the pivotal key of Shiite emergence, which exposes the Malay Muslims to some of the Shiite doctrines.

In the Malaysia context, there was no record of Malay Shiite community before the Iranian revolution in 1979. The earliest entrance of Shiism can be traced from the Indian immigrants who come to Malaysia during 1960's for business purposes and eventually stay here. The Shiism of these Indian immigrants can be categorised into two groups. The first is Taiyibite Bohra (Dawood Bohra) and the second is Isma'ilite Agha Khan Shiite. Furthermore, the Dawood Bohra group owned the Bombay store based in Klang area as they also have the specific cemetery and mosque as well. The number of followers of this group is estimated at 200 to 400 people. ${ }^{91}$ The Agha Khan Group is known as the owner of the Peerbhai shop and live around Klang Valley. The sum of this group follower is smaller than Dawood Bohra Shiite. ${ }^{92}$ However, both groups are not found to propagate their beliefs and teachings over the Sunnite community. Rather they practiced Shiism by themselves and imposed it on family members as well as their new generation.

According to the Jabatan Kemajuan Islam Malaysia (JAKIM), Shiite propaganda only became active in spreading their ideology in Malaysia after the success of the Iranian Revolution in 1979. The teachings of Shiism have been carried out by Iran-based Shiite, Ithnā 'Ashriyyah (Twelver). The Iran's Revolution in 1979 was the starting point of the Shiites exporting their idealism, teaching and doctrines all over the world. Furthermore, in these recent years, Shiite groups have gotten support from the locals as a number of them is increasing day by day. According to JAKIM, the number of Shiite followers in Malaysia is around $3000 .^{93}$ However, the number of Shiite followers can be greater than what has been recorded by JAKIM, as they practice 'taqiyyah' to hide their identity as a Shiite. As a result, the Shiite followers are increasing in terms of number and its emergence is predominant.

Moreover, there are four main factors contributing to the growing

${ }^{90}$ Ibid.; AbdulFatah Haron Ibrahim, Allah Antara Tasawwuf Dengan Akidah,(Kuala Lumpur: Dewan Bahasa dan Pustaka,2008), pp. 204-220.

${ }^{91}$ Zamihan Mat Zain, Bahaya Penyelewengan Syiah, Seminar Majlis Penjelasan Fatwa, (Kuala Lumpur: n.p, 2013), p. 15.

92 Zamihan, Bahaya Penyelewengan, 16, Aizam, Soal Jawab, p. 36.

${ }^{93}$ Ibid., p. 32. 
number of Shiite followers. ${ }^{94}$ Firstly, it is because of the Malaysian students who are sent to Iran. This kind of activity has begun since 20 years ago. In 1984, six students from Darul al-Falah religious school of Malacca were sent to one of the Universities of Qum in Iran. After that, ten from the same school and Darul al-Atiq in Johor Bharu were sent to Pakistan to learn Persian language and Shiite teachings there. As soon as they returned, they became the missionaries and spread Shiism in Malaysia. ${ }^{95}$ Secondly, it is also because of the official and unofficial visits from the group leaders of Iran to Malaysia and vice versa. The visit included a talk program and explanation regarding the 'aqidah and teachings of Shiism. ${ }^{96}$ Meanwhile, Malaysians also did not miss the opportunity to visit Iran and attend the program that had been arranged by the Shiite organizations in India, Bangladesh, Australia, Thailand and Kuala Lumpur. ${ }^{97}$ Thirdly, it was also due to the spread of their ideologies, doctrines and teachings through reading materials such as pamphlets, books and magazines such as Fatimah and al-Quds magazines, the books that has been translated into the Malay language such as Nahj al-Haq wa Kashf al-Sidq. ${ }^{98}$ Fourthly, the relationship between Iranian Shiites and Malaysian politicians. Iran's revolution in 1979 had inspired the Muslim world: It was seen a sign of Islamic glory and success which maintained the essence of Islamic identity. During this time, Iran became a model to other Muslim countries including Malaysia.

Politically, the diplomatic tie between Iran and Malaysia became closer and many Malaysian politicians visited Iran. In Malaysia, the political party which has a long mutual relationship with Iran is Parti Islam se-Malaysia (PAS). The mark of the good relationship between these two organisations can be seen through the sending of young political leaders of PAS to Iran for learning purposes. Until today, PAS

94 Che Mat bin Che Min, "Gerakan Syiah Dan Pengaruhnya Di Malaysia", Ajaran Sesat: Kemunculan, Bahayanya, Pemulihannya, dalam Koleksi Kertas Kerja Seminar Aqidah MABIMS, Ajaran Sesat: Kemunculannya, Bahayanya, Pemulihannya, (1994), pp. 99-101.

${ }^{95}$ Ibid., p. 98.

96 Ibid.

97 Bahagian Penyelidikan Dan Pembangunan, Himpunan Ajaran, Amalan, Dan Fahaman Yang Telah Diwartakan Menyeleweng Dan Sesat Dalam Negeri Selangor Sepanjang Abad Dua Puluh, op. cit, ms. 132.

${ }^{98}$ Che Mat Che Min..., 101-102. 
has a moderate opinion regarding Shiism. ${ }^{99}$ Lately, Parti Amanah Negara (AMANAH) is seen to have a friendly approach to Shiism. ${ }^{100}$ This claim can be proven by the top leaders of the party who have special recognition and a good relationship with Iranian Shiites. ${ }^{101}$

The development of Shiism in Malaysia among the locals has been carried out secretly as its influence has reached the entire country. ${ }^{102}$ States such as Selangor, Kedah, Johor, Pahang and Malacca are among top states which are being influenced by Shiite teaching. However, every religious authority in those states has taken this matter seriously as the teaching of Shiite is banned from being preached. It has been stated in the states's religious laws. Thus, the Shiite influence in Malaysia is significant as it reaches every state and it cannot be undermined.

\section{The Emergence and Development of Shiism in Malacca}

Malacca is one of the states in Malaysia located in southern part of the country. The existence of Shiism in Malacca is the result of the emergence of Shiite influence in Malaysia. It cannot be denied that the influences of Shiite continuously threaten the community of Muslims, as some Muslims are influenced by Shiite thoughts and teachings.

According to Jabatan Agama Islam Melaka (JAIM), which responsible for the Islamic affairs in Malacca, the trend of Shiite practice in Malacca comes from a group of Ithnā 'Ashriyyah or known as Twelver. This is the only group that is prominent and they have spread in Malacca. Sometimes, they introduce themselves as the Ja'farite or 'AB' (Ahl al-Bayt) to the locals. They claim that they are following the Twelver Imāmite in creed ('aqìdah) and Ja 'farite in practices or fiqh. ${ }^{103}$ Furthermore, in the interview session with an officer of JAIM reveals that a number of local Malay Shiite in Malacca is around 250 people. These are locals who identify themselves as the Malay Shiite and

99 Ibid., 98-102, Muhammad Asri Muda, Memoir Politik Asri (Selangor: Percetakan Watan Sdn. Bhd, 1993), pp. 112-115.

100 Khairil Ashraf, "Mat Sabu Pertahan Hadi Lawat Iran," Free Malaysia Today <http://www. freemalaysiatoday.com/category/bahasa/2016/12/22/amanah-pertahanhak-hadi-lawat-iran/> (accesed 11 January 2017).

${ }^{101}$ Nur Azlina Shaari, "Saya Bukan Syiah, Tapi Ikut Sistem Syiah," MYKMU.net < http://www.mykm u.net/2013/10/jenaka-mat-sabu-saya-bukan-syiah-tapi-ikut-sistemsyiah/> (accessed 10 January 2017).

102 Officer 2, interview by author, Melaka Tengah, Melaka 31 October 2016.

103 Officer 1, interview by author, Melaka Tengah, Melaka 3 March 2016. 
practice Shiite teachings. ${ }^{104}$ However, the total number of Shiite followers is possibly greater from what has been recorded by JAIM since most of them applied taqiyyah (dissimulation) in hiding their identity as a Shiite. Hence, the total number of Malay Shiite followers in Malacca is unconfirmed.

The interview also highlighted some of the areas where the group of Shiites is active. The areas such as Ayer Molek, Duyong, Semabok, Sungai Udang, Umbai and Jasin are among the places where local Shiites live. ${ }^{105}$ There is one hawzah (center for them to learn about Shiite teaching and practice their beliefs) which is located in Taman Semabok Perdana. However, due to operation run by JAIM to rush the hawzah, the location has changed to other places as they are secretly hiding the new hawzah from the public and the religious authority. Only the members know the location of the new hawzah is. ${ }^{106}$ In fact, the act of spreading Shiism in Malacca is conducted in secret. The local Shiites convey Shiism within close circle such as their families, relatives and close friends. Most of them do not openly declare that they are Shiites, but through their practices the Shiite teachings have been expressed. ${ }^{107}$

Generally, Shiism is officially banned from being preached in Malacca by JAIM since $5^{\text {th }}$ May 1997 as JAIM stresses on the necessity to follow Ahl al-Sunnah wa al-Jamā'ah school in 'aqīdah. ${ }^{108}$ It is highlighted in a fatwa ${ }^{109}$ that Shiism is considered a deviant teaching because its ideologies and doctrines contradict with the practices of the majority of Muslims, who are following Ahl al-Sunnah wa alJama ' $a h .{ }^{110}$ The differences in terms of 'aqīdah and fiqh in most cases will create disunity and disharmony within the Muslim community.

\footnotetext{
104 Ibid.

105 Officer 2, interview by author, Melaka Tengah, Melaka 31 October 2016, Officer 1, interview by the author, Melaka Tengah, Melaka 3 March 2016.

${ }^{106}$ Respondent 4, interview by author, Melaka Tengah, Melaka, 15 September 2016.

107 Officer 1, interview by author, Melaka Tengah, Melaka 3 March 2016.

108 Officer 2, interview by author, Melaka Tengah, Melaka 31 October 2016.

109 "(1) Fahaman dan ajaran Syiah adalah bercanggah dan menyeleweng daripada ajaran Islam menurut pegangan Ahli Sunnah Wal Jama'ah serta boleh menjadi ancaman kepada keutuhan agama, kesatuan ummah dan keselamatan serta keamanan Negara. (2) Fahaman dan ajaran ini perlu disekat keseluruhannya dari berkembang di Negeri Melaka. Banyak perkara yang bercanggah dengan pegangan Ahli Sunnah Wal Jama' ah di dalam ajaran dan fahaman Syiah terdiri daripada sudut Aqidah, Syariah dan Akhlak."

110 Ibid.
} 
Precisely, on $24^{\text {th }}$ September 2015, JAIM outlined the details of Shiism which clearly discuss its beliefs, thoughts, practices, characteristics and symbols. Everything that is related to Shiism is not allowed to appear, to be taught, to be testified, to be disseminated and to be practiced publicly, as it will go against the Shari'ah laws in Malacca. Therefore, the extension in elaborating Shiism in a few possibilities and angles in recent year provides the religious authority power to prevent the Shiite influence from growing.

Thus, the Malacca state government takes great effort in countering Shiite influence from being disseminated. The coming of Shiism is not welcomed by the local government which indicates that Shiism is a threat to the state. Since that, it has been monitored carefully by JAIM from time to time. ${ }^{111}$

\section{Cases of Shiism in Malacca}

According to an interview with an officer from the Research and Development Affair of JAIM, there is no specific date or year when Shiism emerged in Malacca since there is no data collected by JAIM. However, in general, the emergence of Shiism in Malacca can be traced back to in the early 1980s after the success of Iran's revolution. This is a starting point where the influence of Shiism rose, and it reached Malaysia. At that time, the Malays were fascinated with what Iran had achieved. Therefore, some of the local Malays sent their children to further education in Iran so that once they finished their studies, they would bring the ideas and spirit of Islam back and return the Muslim ummah to the real teaching of Islam. ${ }^{112}$ Hence, the Iranian Revolution is one of the factors which contributed indirectly to the influence of Shiism in Malacca.

Regarding Shiism, JAIM has been carefully monitoring it through operations based on complaints made by the locals. The officer further added that since Shiites have applied taqiyyah in hiding Shiite identity, it is difficult to recognize and identify local Malay Shiites. As a result, raids are meaningless as JAIM cannot take legal action on them. ${ }^{113}$ However, through the new amendments to the Shari'ah laws on Shiism in September 2015 precisely highlights the details and features of

111 Officer 2, interview by author, Melaka Tengah, Melaka 31 October 2016.

112 Officer 1, interview by author, Melaka Tengah, Melaka 3 March 2016.

113 Officer 2, interview by author, Melaka Tengah, Melaka 31 October 2016. 
Shiism. This makes it easier for JAIM to bring Shiite cases to the Shari' ah court. ${ }^{114}$

Furthermore, there are three major cases related to Shiism in Malacca as stated by the JAIM officer. Firstly, there was a raid on a house located in kampung Paya Dalam, Telok Mas which had been used as an operation centre for the Shiite group to distribute reading materials such as articles, books and pamphlets to all over Malaysia. They aim places like mosques and government departments as focused targets to convey the thoughts and teachings of Shiism. In addition, after a complete investigation, JAIM came to know that the reading materials are sent by Majlis Syi' ah Malaysia (Malaysian Shiite Council) addressed in Ulu Tiram, Johor. During the raid, JAIM found 35,000 reading materials about Shiism and 6000 reading materials such as books and articles to be distributed all over the country. This is the biggest raid on Shiite propaganda in Malaysia. ${ }^{115}$ Besides that, five individuals were arrested during the raid, who was known to be the workers there. According to the JAIM officer, the workers cannot be subjected to Shari'ah laws because all of them are underage and they are not the owners of those reading materials. ${ }^{116}$ In other words, they just worked there and were not involved with Shiite activities.

Secondly, there was a raid of one Shiite family in Felda Kemendor, Jasin in October 2016, who claimed to have ancestors. ${ }^{117}$ This family openly admitted that they are Shiite followers and have been living there (in Felda Kemendor) for a long time. In addition, this operation which was led by JAIM and Polis Diraja Malaysia (PDRM) mananged to arrest two individuals. This operation happened due to the widespread promotion of Shiite propaganda through social platforms like Facebook, thus exposing their identity as Shiites. They uploaded the flags, symbols and information regarding Shiism in order to attract people. Plus, JAIM officer received information that this family planned to practice Shiite rituals since it was 'Ashüra (the tenth day of first month of Islamic calendar). During the raid, there were pictures of Shiite leaders hanging on the wall of the house and books of Shiite teachings as well. Before the raid, this family was invited by JAIM to have a dialogue regarding

\footnotetext{
${ }^{114}$ Officer 2, interview by author, Melaka Tengah, Melaka 31 October 2016. 115 Officer 2, interview by author, Melaka Tengah, Melaka 31 October 2016.

116 BERNAMA, "Melaka Siasat Dalang Sebar Fahaman Syiah" Malaysiakini <http://www.malay siakini.com/news/174300 $\geq$ (accessed in 25 May 2016).

117 Officer 2, interview by author, Melaka Tengah, Melaka 31 October 2016.
} 
their beliefs and practices, but mutual understanding was not achieved between both parties because the family practiced taqiyyah. ${ }^{118}$ This is the root of the problem that failed the negotiation and discussion over the stand of Shiism on Ahl al-Sunnah wa al Jamā'ah.

The third raid took place on $21^{\text {st }}$ November 2016 in two different locations due to espionage activities and local information. The raids took place at a homestay in Umbai and a cyber cafe in Telok Mas. During the raid, there were 21 men and eight women who were involved, all of them Malays. Plus, 15 children were also found as they followed their parents. ${ }^{119}$ In fact, 10 individuals were from Malacca and the rest came from other states. Besides that, there are several objects confiscated by JAIM which symbolize Shiite identity such as reading materials (books, articles and laptop), the Shiite flag, banner, Karbala's rocks and keris, (a Malay dagger). ${ }^{120}$ All detained are known as members of the group of al-Anșār Imām al-Mahdi, which is among the main groups who propagate Shiism in the local community. ${ }^{121}$ According to an investigation by JAIM, this group is actively practicing Shiite teaching in which they frequently meet and gather. This raid is the latest operation run by the religious authority after the local Shiite group organised a gathering for Shiite followers even the common people could possibly join it. Hence, it shows that the group tries to spread their belief and teaching publicly.

\section{Conclusion}

Due to long history in Muslim tradition, Shiism has established the strong foundation among its proponents and followers. The categorization of Shiite groups indicates that the development of its basic teachings and tenets from time to time has resulted in the emergence of the dominant group of Shiism; the Twelver or Ithna 'Ashriyyah which is the largest Shiite group in the world. The spread of

\footnotetext{
118 Officer 2, interview by author, Melaka Tengah, Melaka 31 October 2016.

${ }^{119}$ Siti Sharosamirah Shaharaman, "Homestay Jadi Markas Syiah" Sinar Harian Online <http://www.sinarharian.com.my/edisi/melaka-ns/homestay-jadi-markas-syiah1.588559> (accessed in 25 November 2016).

${ }^{120}$ Mohd Zuhairie Zubir, "JAIM Serbu Markas Syiah, 29 Ditahan” Berita Harian Online <https://www. youtube.com/watch?v=C6FRWlb3QK4>, (accessed in 23 November 2016).

121 Nurul Fhatihah Zakinan, "JAIM Serbu Markas Syiah, 29 Ditahan" BH Online <http://www. bharian.com.my/node/215022 >, (accessed in 23 November 2016).
} 
Shiism to the Muslim world is neither perception nor accusation; its influence succeeds to reach Muslims in Malaysia; particularly in Melaka. The recent activities of Malay Shiites in Melaka reflect the movement of disseminating Shiism has been actively propagated among the close circle of them such as relatives and friends. This scene has put the religious authority in alert in combating any teaching which misled and against the teaching of Ahl al-Sunnah wa al-Jamā' $a h$.

\section{References}

'Abd al-Hamīd Fattāh, 'Irfān. Dirāsāt fì al-Firaq wa al-'Aqā'id al-Islāmiyyah. (Baghdād: Maṭba'ah al-Irshād, 1967).

Abū Zahrah, Muhammad. Tārīkh al-Madhāhib al-Islāmiyyah. (Cairo: Dār al-Fikr al'Arabī, 1960).

Aizam Mas'ud. Soal Jawab Isu Syiah di Malaysia. (Putrajaya: Reka Cetak Sdn, Bhd. 2013).

Al-Aṣfahān̄̄, Abū al-Qāsim al-Ḥusayn ibn Muḥammad Rāghib Mufradāt Alfāz alQur'ān. (Dimashq: Dār al-Qalam, 2002).

Al-Baghdādī, Abū Manșūr 'Abd al-Qāhir ibn Țāhir. Al-Farq Bayna al-Firaq, (New Delhi: Cosmo Publications, 2011).

Al-Bukhārī, Muḥammad bin Ismā‘̄̄il. Al-Jāmi ' al-Sahạhh al-Bukhārī. (Al-Qāhirah: AlMaktabah al-Salafiyah,1980).

Al-Maghribī, 'Al̄̄ 'Abd al-Fattāḥ. Al-Firaq al-Kalāmiyyah al-Islāmiyyah: Madkhal wa Dirāsatuh, (Al-Qāhirah: Maktab al-Wahbah, 1995).

Al-Nawbakhtī, Abū Muḥammad al-Ḥassan bin Mūsā. Firaq al-Shī‘ah. (Istanbul: Mațba'ah al-Daulah, 1931).

Al-Samhị̄, Sulaymān ibn Rajā'. Al-'Aqīdah Ahl al-Bayt bayna al-Ifrāt wa al-Tafrìt, (Riyāụ: Dār Aḍ̂ā' al-Salaf,2004).

BERNAMA, "Melaka Siasat Dalang Sebar Fahaman Syiah" Malaysiakini <http://www.malay siakini.com/news/174300_(accessed in 25 May 2016).

Che Mat bin Che Min. "Gerakan Syiah Dan Pengaruhnya Di Malaysia", Ajaran Sesat: Kemunculan, Bahayanya, Pemulihannya, dalam Koleksi Kertas Kerja Seminar Aqidah MABIMS, Ajaran Sesat: Kemunculannya, Bahayanya, Pemulihannya. (1993).

Hamzah, Muhammad. Al-Ta'lluf bayna al-Firaq al-Islāmiyyah, (Damascus: Dār alQutaybah, 1985).

Ibn Khaldūn, Abū Zayd 'Abd al-Raḥmān ibn Muḥammad, Al-Muqaddimah, (New Jersey: Princeton University Press,1967).

Ibn Manẓūr, Muhammad bin Mukram. Lisān al- 'Arab, (Bayrūt: Dār al-Fikr,1980). 
Khairil Ashraf, "Mat Sabu Pertahan Hadi Lawat Iran," Free Malaysia Today <http://www. reemalaysiatoday.com/category/bahasa/2016/12/22/amanahpertahan-hak-hadi-lawat-iran/> (accesed 11 January 2017).

Macdonald, Duncan B. Development of Muslim Theology, Jurisprudence and Constitutional Theory, (New York: Charles Scribner's Sons, 1903).

Mazrū'ah, Maḥmūd Muḥammad. Al-Firaq al-Islāmiyyah, (Madīnah: Dār al-Riḍā, 2008).

Mohd Zuhairie Zubir, "JAIM Serbu Markas Syiah, 29 Ditahan" Berita Harian Online <https://www. youtube.com/watch?v=C6FRWlb3QK4>, (accessed in 23 November, 2016).

Muassasah al-Balagh. Ahl al-Bayt: Maqāmuhum Manhajuhum Masāruhum, (Iran: AlBalagh Foundation,1977).

Muhammad Asri Muda. Memoir Politik Asri, (Selangor: Percetakan Watan Sdn. Bhd.,1993).

Naḍ̄ī, Al-Bir Nāșir. Madkhal ilā al-Firaq al-Islāmiyyah: Al-Siyāsah wa al-Kalāmiyyah, (Bayrūt: Dār al-Mashriq, 1989).

Nur Azlina Shaari, "Saya Bukan Syiah, Tapi Ikut Sistem Syiah," MYKMU.net < http://www.mykm u.net/2013/10/jenaka-mat-sabu-saya-bukan-syiah-tapi-ikutsistem- $\quad$ syiah/> (accessed 10 January 2017).

Nurul Fhatihah Zakinan, "JAIM Serbu Markas Syiah, 29 Ditahan" BH Online <http://www. bharian.com.my/node/215022 >, (accessed in 23 November 2016).

Al-Shahrastān̄̄, Muḥammad b. 'Abd al-Karīm. Kitāb al-Milal wa al-Niḥal, (London, Kegan Paul International,1984).

Siti Sharosamirah Shaharaman, "Homestay Jadi Markas Syiah" Sinar Harian Online <http://www.sinarharian.com.my/edisi/melaka-ns/homestay-jadi-markas-syiah1.588559> (accessed in 25 November 2016).

Watt, W. Montgomery. The Formative Period of Islamic Thought, (Edinburgh:Edinburgh University Press, 1973).

Zāhir, Iḥsān Ilāhī. Al-Shī‘ah wa Ahl al-Bayt, (Al-Qāhirah: Dār al-I'tișām, 1986).

Zamihan Mat Zain. Bahaya Penyelewengan Syiah, Seminar Majlis Penjelasan Fatwa,(Kuala Lumpur: n.p, 2013). 